\title{
EVALUATION OF PHYSIOLOGIC RACES AND VIRULENCE OF Puccinia striiformis ON HOST DIFFERENTIAL GENOTYPES, SOME NEAR ISOGENIC LINES AND COMMERCIAL CVs., AT SEEDLING AND ADULT STAGES IN EGYPT
}

Abu Aly, A.A.M.*; M. I. Gouda**and W. A. Youssief *

* Wheat Dis. Res. Dep., Plant Pathology Res. Inst., A.R.C. Giza, Egypt.

**Maize and Sugar Crops Dis. Res. Dep., Plant Pathology Res. Inst. A.R.C. Giza, Egypt.

\begin{abstract}
Twelve pathotypes of Puccinia striiformis from rusted samples collected during 2004/2005. These races were designated as 2 E0, 2E22, 6E0, 6E18, 150E82, 198E150, 198E156, 6E148, 6E150, 38E134, 230E134 and 229E223. Races 2E0, 6E0 and 2E22 were the most frequency ones. Most of the races exhibited high level of virulence on the local cultivars at seedling stage. The isogenic lines carrying $\mathrm{Yr} 6, \mathrm{Yr}$ 7, $Y r$ 8, $Y r$ 9, $Y r$ 12, $Y r 18$ and $Y r A$ are considered to be susceptible at both seedling and adult stages. On the other hand, the isogenic lines carrying $Y r 1, Y r 5, Y r 15, Y r$ 17, $Y r 27$ and $Y r$ sp exhibited high level of resistance at both seedling and adult stages with the exception of Sids-7 and Sids- 9 cultivars most of the Egyptian cultivars are considered to be resistant at adult stage. The resistant line can be used as sources of resistance in the breeding program to yellow rust in Egypt.
\end{abstract}

\section{INTRODUCTION}

Stripe rust caused by Puccinia striiformis $\mathrm{F}$. sp. tritci is one of the most important diseases of wheat in the world. In Egypt the first yellow rust epidemic was recorded in 1967. However, during 1990's three major epidemics were recorded in 1995, 1997 and 1999. Sporadic infections were observed during the other years (Abdel - Hak et al., 1972 and Abu El-Naga, et al.,1999). The most important stripe rust epidemic occurred in 1995 particularly in the Northern and Southern Delta areas, yield of most of popular cultivars (Sakha 8, Sakha 69, Giza 163, 164, Gemmeiza-1, -3 and Sids-7, -9) were significantly reduced due to yellow rust infection.

Seedling resistance is usually race specific and can be recognized by its characteristic resistance type at all plant stages (Hong and Singh, 1996). Adult resistance can be either race specific or race non-specific and is usually better recognized after the seedling stage (Johnson, 1988).

Several high yielding spring wheat varieties possess adult plant resistance (Singh, 1992 \& Singh and Rajaram, 1994). Hence the objective of this study was to assess physiologic races of the wheat yellow rust pathogen and the effectiveness of the resistance gene and to study the reactions of commonly grown cultivars. 
Abu Aly, A.A.M. et al.

\section{MATERIALS AND METHODS}

Virulence/avirulence survey of cereal rust fungi have traditionally used differential host genotypes that express resistance or susceptible in susceptibility the seedling stage (Kolme, 1997).

In this experiment stripe rust populations were clarified for their virulence pathotypes and pathogenic variations using two methods.

The first method was the evaluation of seedling of differential genotypes. A set of the World and European wheat yellow rust differentials as proposed by ( Johnson et al., 1972 ). (Table 1) was used for this experiment, some commercial local wheat cultivars and some isogenic lines Yr's. The second method was evaluation of differential genotypes, monogenic lines and local wheat cultivars at adult stage (booting). Evaluation of seedling stages collections of 180 samples (leaves and spikes) were obtained at heading stage from differential cultivars in the yellow rust from commercial fields in Egypt during the growing season of 2003/2004 and 2004/2005 from different locations i.e. (Kafr El-Sheikh, Gharbyia, Dakahlyia and Damietta). The collected samples were purified and multiplied on susceptible wheat cv. Giza-160. Urediniospores were used to inoculate 7-10 days-old seedlings of the yellow rust differential genotypes and commercial cvs. (Table 1). Inoculated plants were placed for $24 \mathrm{~h}$ in a dew chamber at $10^{\circ} \mathrm{C}$, then they were transferred to a growth chamber at $15-17^{\circ} \mathrm{C}$ with $16 \mathrm{~h} / 8 \mathrm{~h}$ day/night light intensity was estimated by 7500 lux. Infection types were assessed 17-20 days after inoculation using the 0 to 9 scale (McNeal et al., 1971).

Table (1): Yellow rust differential cultivars, used for identification of wheat yellow rust pathotypes (races).

\begin{tabular}{|l|c|c|}
\hline \multicolumn{1}{|c|}{ Differential* cultivars } & Decanery value & Yr resistance gene \\
\hline World set : & $1\left(=2^{\circ}\right)$ & 1 \\
Chinese 166 & $2\left(=2^{1}\right)$ & 7 \\
Lee & $4\left(=2^{2}\right)$ & $6(1)$ \\
Heines Kolben & $8\left(=2^{3}\right)$ & $3 \mathrm{~V}$ \\
Vilmorin 23 & $16\left(=2^{4}\right)$ & 10 \\
Moro & $32\left(=2^{5}\right)$ & $\mathrm{SD}$ \\
Strubes Dickkopf & $64\left(=2^{6}\right)$ & $\mathrm{SU}$ \\
Suwon 92 x Omar & $128\left(=2^{7}\right)$ & $9,2+$ \\
Clement & $256\left(=2^{8}\right)$ & 5 \\
Triticum spelta f.sp. album & $1\left(=2^{\circ}\right)$ & $4+$ \\
European set : & $2\left(=2^{1}\right)$ & $7+$ \\
Hybrid 46 & $4\left(=2^{2}\right)$ & $6,2+$ \\
Reichersberg 42 & $8\left(=2^{3}\right)$ & $\mathrm{ND}$ \\
Heines peko & $16\left(=2^{4}\right)$ & 8 \\
Nord Desprez & $32\left(=2^{5}\right)$ & $\mathrm{CV}$ \\
Compare & $64\left(=2^{6}\right)$ & $\mathrm{SP}$ \\
Carstens V & $128\left(=2^{7}\right)$ & $2,11+$ \\
Spaldings Prolific & Heines VII &
\end{tabular}

* Source of seeds R.W. Stubbs, IPO. The Netherlands. 
Infection types equal to or higher than 7 were considered susceptible and those less than 7 were considered resistant in turn the aggressive races are considered virulent, avirulent.

Evaluation of differential genotypes, monogenic lines and commercial cvs. against stripe rust infection under field conditions.

Two rows for each of the differential genotype, monogenic liens and commercial cvs. were sown in $2 \mathrm{~m}$ long and $30 \mathrm{~cm}$ apart. A mixture of highly susceptible wheat cultivars (Giza 160, Giza 163, Sids-7, -9 and Sakha 69) was sown around the experiment to disseminate the urediospores of the pathogen Puccinia striiformis inoculation of urediospores was achieved at booting stage on spreader plants around the experiment according to the method of (Tervet and Cassel, 1951). Severity of infection (0 to 100\%) and reaction type $(R, S)$ was applied as designated by (Peterson et al., 1948). The experiment was evaluated at all testing sites (Kafr El-Sheikh, and Damietta).

\section{RESULTS}

Identification of physiologic races during the first season 2003/2004. Data presented in Table (2) revealed the presence of 8 physiologic races of Puccinia striiformis f. sp. tritici West during 2004/2005, these races were identified as 2E0, 2E22, 6E0, 6E18, 150E82, 198E150, 198E156 and 229E223 according to their reactions on both World and European differentials. Data in the same table also revealed that race 2E22 was found only once in Kafr El-Sheikh.

Table (2): Yellow rust races identified in Egypt and their distribution during 2004/2005 and 2005/2006.

\begin{tabular}{|l|c|c|c|c|c|c|c|}
\hline \multicolumn{4}{|c|}{ First season } & \multicolumn{5}{c|}{ Second season } \\
\hline Physiologic races & ${ }^{\mathrm{a}}$ A & B & C & Physiologic races & A & B & C \\
\hline 2E0 & ${ }^{\mathrm{b}}+$ & + & + & $2 \mathrm{E} 0$ & + & + & + \\
2E22 & + & $-\mathrm{c}$ & - & $6 \mathrm{E} 0$ & + & + & + \\
6E0 & + & + & + & $6 \mathrm{E} 148$ & + & + & + \\
6E18 & + & + & + & $6 \mathrm{E} 150$ & + & + & + \\
150E82 & + & + & + & $38 \mathrm{E} 134$ & + & + & + \\
198E150 & + & - & + & $230 \mathrm{E} 134$ & + & + & + \\
198E156 & + & + & + & & & & \\
229E223 & + & + & + & & & & \\
\hline
\end{tabular}

${ }^{\mathrm{a}}=$ Kafr El-Sheikh, Dakahlyia and Damietta

${ }^{b}=$ Presence of physiologic races.

c = absence of physiologic races.

Most of these races were virulent to the tested genotypes with the exception of 2E0, 6E0 and to some extent $6 \mathrm{E} 18$ and 2E22.

Regarding the second season 2005/2006 data presented in the same table reveal that 60 collected stripe rust samples from different locations in Egypt are identified to six physiologic races named 2E0, 6E0, 6E148, 6E150, $38 \mathrm{E} 134$ and 230E134. 
Abu Aly, A.A.M. et al.

T3

1200 
J. Agric. Sci. Mansoura Univ., 34(2), February, 2009

T3c

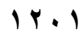


Abu Aly, A.A.M. et al.

Significant changes in race composition were identified using the world and European differential sets Table 3. The composition of physiologic races found in 2005 and 2006 differed greatly on the world and European differential set. With the exception of races $2 \mathrm{E} 0$ and $6 \mathrm{E} 0$ which were observed during two seasons of the study.

Whereas 229E223 was virulent to $Y r_{1}, 7,6-2, \mathrm{SD}, \mathrm{SU}, 9-2 ; 4+, 7+6$ ,2+, ND, 8, SP and 2+. Race 2E0 and 6E0 was a virulent to most European and all world differential set.

Races identified in two years such as 198E150, 198E156, 229E223 and 230E134, have wider spectra of virulence for yellow rust resistance genes than races $2 \mathrm{E} 0,6 \mathrm{E} 0$ and $6 \mathrm{E} 18$. However, the yellow rust population in the country consists of number of pathotypes that differ in their pathogenicity toward the host plant some pathotypes such as 2E0, 6E0 and 6E18 can attack two or three resistance genes in the host plant and some pathotypes such as 198E156, 229E223 and 230E134 can attack 12 identified genes in the host plant.

The relative frequency of yellow rust races and their distribution (Table 4) was determined from the survey samples of 2004-2005 crop season in North Delta. The data reveal that race 2E0 was the most frequent $(18.54 \%)$ followed by $6 \mathrm{E} 0(17.08 \%), 2 \mathrm{E} 22(14.64 \%), 6 \mathrm{E} 148(12.20 \%)$ and both $6 \mathrm{E} 18$ and $6 \mathrm{E} 150(7.32 \%)$.

Table (4): Pathotypes of wheat stripe rust (Puccinia striiformis), their frequency (\%) and distribution in Northern and Southern Delta during 2004/2005 and 2005/2006.

\begin{tabular}{|l|c|c|l|}
\hline Pathotypes & $\begin{array}{c}\text { Number of } \\
\text { samples }\end{array}$ & $\begin{array}{c}\text { Frequency } \\
(\%)\end{array}$ & \multicolumn{1}{|c|}{ Distribution } \\
\hline 2E0 & 38 & 18.54 & Sakha, Damietta and Dakahlyia \\
2E22 & 30 & 14.64 & Dakahlyia and Sharkyia \\
6E0 & 35 & 17.08 & Sakha, Damietta and Dakahlyia \\
6E18 & 15 & 7.32 & Dakahlyia \\
150E82 & 9 & 4.39 & Sakha \\
198E150 & 5 & 2.43 & Sakha \\
198E156 & 7 & 3.42 & Sakha \\
229E223 & 13 & 6.63 & Sakha \\
6E148 & 25 & 12.20 & Sakha, Dakahlyia and Damietta \\
6E150 & 15 & 7.32 & Sakha \\
38E134 & 5 & 2.43 & Sakha, Damietta and Dakahlyia \\
230E134 & 8 & 3.90 & Sakha and Damietta \\
\hline
\end{tabular}

\section{Reaction of monogenic lines and commercial cvs. at seedling stage:}

As clearly shown in Table (3), 22 wheat $Y r$ near isogenic liens were evaluated against stripe rust infection when inoculated with pathotypes of Puccinia striiformis at seedling stage during two seasons. The data indicated that all races, possessed virulence for near isogenics lines $\mathrm{Yr} 6, \mathrm{Yr} 7, \mathrm{Yr} 8, \mathrm{Yr}$ 9, $Y r 18$ and $Y r$ A. Races $150 \mathrm{E} 82$, was virulent on the near isogenic line $\mathrm{Yr}$ 10. Races 198E150, 198E156, 229E223, 38E134 and 230E134 was virulent on the near isogenic lines $\operatorname{Yr} 11$, and 12. 
Results in the same table reveal that 11 wheat varieties under artificial inoculation was using same pathotypes which all tested varieties were susceptible and giving reaction ranged from (7-9) s.

Race 6E0 was found in Sakha, Dakahlyia and Damietta Table (4) this race isolated in Sakha, Dakahlyia and Damietta from infected leaves of Heins Kolben and from bread wheat cv. Sakha 8. Race 2E0 was isolated from differential genotype Lee in Sakha, Dakahlyia and Damietta. Race 2E22 and 38E134 were isolated from leaf samples of the differential genotype Reichersberg 42 in Sakha, Dakahlyia and Damietta. Three physiologic 198E150, 229E223 and 230E134 were isolated from cv. Giza 163 in Sakha and Damietta. Races were identified using rust samples developed on cultivars that have specific genes or gene combination.

Stripe rust samples were collected during the growing seasons of 2004/2005 and 2005/2006 from different location were made from selected differential genotypes associated with resistance gene. The selected lines were exposed in trap nurseries to natural and some cultivar yellow rust infection Table (5) shows the $P$. strriformis physiological races and the corresponding cultivars from which they were isolated.

Table (5): Yellow rust physiological races isolated from specific differential lines or wheat cultivars in Egypt.

\begin{tabular}{|l|c|c|}
\hline \multicolumn{1}{|c|}{ Differential genotypes cultivars } & Resistance gene & Physiologic races \\
\hline Heines Kolben, cultivars Sak.69, Sak.8, Sids 9 and 7 & Yr 6,- & $6 \mathrm{E} 0$ \\
Lee & Yr 7,- & $2 \mathrm{E} 0$ \\
Compare & Yr 8 & $6 \mathrm{E} 18$ \\
Reichersberg 42 & Yr 7+ & $2 \mathrm{E} 22$ \\
Cultivars Sakha 69 & - & $150 \mathrm{E} 82$ \\
Jupateco R & Yr 18 & $198 \mathrm{E} 150$ \\
Heines VII & Yr 2 & $198 \mathrm{E} 156$ \\
SupatecoR, cvs.Sak.69,Sak.8,Giza163, Sids7 and 9 & Yr 18 \\
Compare & Yr 8 & $229 \mathrm{E} 223$ \\
Lee & Yr 7- & $6 \mathrm{E} 148$ \\
Reichersberg 42 & Yr 7 & $6 \mathrm{E} 150$ \\
Jupateco R & Yr 18 & $38 \mathrm{E} 134$ \\
\hline
\end{tabular}

\section{Field observations:}

The results of adult plant stage showed that many of the lines had resistant reaction to yellow rust (Table 6). Of these differentials, Chinese 166, .Vilomorin 23, Moro, Strubes Dickkopf, Suwon $92 \times$ Omar, Triticum spelta f.sp., album, Carsten $\mathrm{V}$ and Spaldings prolific carrying respective $\mathrm{Yr}$ resistance factors $Y r$ 1, Yr 3V, Yr $10 \mathrm{Yr}$ SD, Yr Su, Yr 5, Yr CV and Yr SP were resistant through the study between 2004-2006 in two locations (Table 6). The differential Lee, Heines Kolben, Clement, Rechiersberg 42, Heines Peko, Nord Desperz, Compare and Heines VII, carrying $\operatorname{Yr} 7, \operatorname{Yr} 6, \operatorname{Yr} 9, \mathrm{Yr}$ $2+, Y r 7+, \operatorname{Yr} 6, \operatorname{Yr} 2+, \operatorname{Yr} 8$ and $Y r 2,11+$, respectively were susceptible in two seasons and two locations. The scores were variable between 10MS-90S in two seasons. In contrast to these genotypes some others gave defferent infection type.

At all the testing sites reported in this study the susceptible cultivars Avocets, and Aroonas were in fact the most susceptible cultivars in the field. 
Abu Aly, A.A.M. et al.

The isogenic lines carrying $Y r 6, Y r 7, Y r 8, Y r 9, Y r 12, Y r 17$ and $Y r$ SP gave susceptible reading in two years though the second season severity was low.

Table (6): Reaction of differential genotypes to yellow rust at different locations throughout two seasons,2004/2005 and 2005/2006.

\begin{tabular}{|l|c|c|c|c|c|}
\hline \multicolumn{1}{|c|}{ Differential Cvs. } & \multirow{2}{*}{ Yr gene } & \multicolumn{2}{c|}{ First season } & \multicolumn{2}{c|}{ Second season } \\
\cline { 3 - 6 } & & A & B & A & B \\
\hline Chinese 166 & 1 & 0 & 0 & 0 & 0 \\
Lee & 7 & $90 \mathrm{~S}$ & $60 \mathrm{~S}$ & $60 \mathrm{~S}$ & $60 \mathrm{~S}$ \\
Heines Kolben & 6 & $90 \mathrm{~S}$ & $80 \mathrm{~S}$ & $70 \mathrm{~S}$ & $70 \mathrm{~S}$ \\
Vilmorin 23 & $3 \mathrm{~V}$ & $20 \mathrm{R}$ & $20 \mathrm{R}$ & 0 & 0 \\
Moro & 10 & 0 & 0 & 0 & 0 \\
Strubes Dickkopf & $\mathrm{SD}$ & 0 & 0 & 0 & 0 \\
Suwon 92 x Omar & $\mathrm{SU}$ & 0 & 0 & 0 & 0 \\
Clement & $9,2+$ & $60 \mathrm{~S}$ & $40 \mathrm{~S}$ & $50 \mathrm{~S}$ & $50 \mathrm{~S}$ \\
Triticum spelta album & 5 & 0 & 0 & 0 & 0 \\
Hybrid46 & $4+$ & $30 \mathrm{MS}$ & $20 \mathrm{MS}$ & 0 & 0 \\
Reichersberg 42 & $7+$ & $90 \mathrm{~S}$ & $60 \mathrm{~S}$ & $80 \mathrm{~S}$ & $80 \mathrm{~S}$ \\
Heines Peko & $6,2+$ & $80 \mathrm{~S}$ & $80 \mathrm{~S}$ & $60 \mathrm{~S}$ & $60 \mathrm{~S}$ \\
Nord Desprez & $\mathrm{ND}$ & $20 \mathrm{MS}$ & $10 \mathrm{MS}$ & $5 \mathrm{MR}$ & $5 \mathrm{MR}$ \\
Compare & 8 & $60 \mathrm{~S}$ & $50 \mathrm{~S}$ & $40 \mathrm{~S}$ & $30 \mathrm{~S}$ \\
Carstens V & $\mathrm{CV}$ & 0 & 0 & 0 & 0 \\
Spaldings profilic & $\mathrm{SP}$ & 0 & 0 & 0 & 0 \\
Heines VII & $2,11+$ & $80 \mathrm{~S}$ & $80 \mathrm{~S}$ & $60 \mathrm{~S}$ & $40 \mathrm{~S}$ \\
\hline
\end{tabular}

A = location Kafr El-Sheikh B = Location Damietta

The susceptible cultivars confirms the presence of yellow rust disease at the testing site. Significant changes were observed in the virulence pattern of Yr populations in 2004/2005.

The virulence for the isogenic line $Y r 11$ and $Y r 27$ was recorded for the first season in two sites were scored 30 MS-20 MS. However, the two entries in the second season were resistant type reaction was 5MR-10 MR.

Climatic conditions such as temperature, light and humidity may have been playing a role in expression of some genes.

On the other hand, entries in the Ner isogenic lines which was included in the study, the $\operatorname{Yr} 1, \operatorname{Yr} 5, \operatorname{Yr} 15, \operatorname{Yr} 17, \operatorname{Yr} 27, \operatorname{Yr} \mathrm{SP}$ and entries Gobustein and Bohuth 6 were resistant in two sites.

The commonly grown wheat cultivars in Egypt varied in their resistance to yellow rust. Table 7 shows the relative reaction of common wheat cultivars to yellow rust at adult stage the results confirmed the resistance of the cultivars Sakha 61, Sakha 93, Sakha 94, Giza 168, Gemmeiza 9, 10 and Sids 1. Sakha 69 and Sids 7, 9 were as expected susceptible and will not be recommended for further cultivation.

The resistance could be useful for breeding for resistance to yellow rust in Egypt. 
Table (7): Infection type and severity of some near isogenic lines and some commercial Cvs. to yellow rust at two different locations.

\begin{tabular}{|c|c|c|c|c|c|}
\hline \multirow{2}{*}{ Isogenic lines: } & \multirow{2}{*}{ Yrgene } & \multicolumn{2}{|c|}{ First season } & \multicolumn{2}{|c|}{ Second season } \\
\hline & & A & B & A & B \\
\hline Yr 1/*6 Avocets & Yr1 & 0 & 0 & 0 & 0 \\
\hline Yr $5 /{ }^{*} 6$ Avocets & $\operatorname{Yr} 5$ & 0 & 0 & 0 & 0 \\
\hline $\operatorname{Yr} 6 /{ }^{*} 6$ Avocets & Yr6 & $80 S$ & $60 \mathrm{~s}$ & $40 S$ & $30 s$ \\
\hline Yr 7/*6 Avocets & $\operatorname{Yr} 7$ & $90 \mathrm{~s}$ & $90 \mathrm{~s}$ & $50 \mathrm{~S}$ & 205 \\
\hline Yr 8/*6 Avocets & $\operatorname{Yr} 8$ & $80 \mathrm{~S}$ & $80 \mathrm{~S}$ & $40 \mathrm{~S}$ & $20 S$ \\
\hline $\operatorname{Yr} 9 /{ }^{*} 6$ Avocets & $\operatorname{Yr} 9$ & $60 \mathrm{~S}$ & $50 \mathrm{~S}$ & $60 \mathrm{~S}$ & $40 \mathrm{~S}$ \\
\hline Yr 10/*6 Avocets & Yr 10 & 0 & 0 & 0 & 0 \\
\hline$Y r 11{ }^{*} 6$ Avocets & Yr11 & $30 \mathrm{MS}$ & $20 \mathrm{MS}$ & $10 \mathrm{Mr}$ & $5 \mathrm{Mr}$ \\
\hline Yr 12/*6 Avocets & Yr 12 & $30 S$ & $20 S$ & $20 S$ & $20 \mathrm{~S}$ \\
\hline $\operatorname{Yr} 15^{*} 6$ Avocets & Yr 15 & 0 & 0 & 0 & 0 \\
\hline Yr 18/*6 Avocets & Yr 18 & $90 \mathrm{~s}$ & $70 \mathrm{~S}$ & $30 \mathrm{MS}$ & $30 \mathrm{MS}$ \\
\hline Yr 17/*6 Avocets & Yr 17 & 0 & 0 & 0 & 0 \\
\hline Yr 26/*6 Avocets & Yr26 & $30 \mathrm{MS}$ & $20 \mathrm{MS}$ & $10 \mathrm{MR}$ & $10 \mathrm{MR}$ \\
\hline Yr $27 /^{\star} 6$ Avocets & Yr 27 & 0 & 0 & 0 & 0 \\
\hline Yr A /Avocets & YrA & $80 \mathrm{~s}$ & $70 \mathrm{~s}$ & $40 \mathrm{~S}$ & $30 \mathrm{~s}$ \\
\hline YrSP/6 Avocets & Yr SP & 0 & 0 & 0 & 0 \\
\hline Avocet S & & $100 \mathrm{~S}$ & $100 \mathrm{~S}$ & $70 \mathrm{~s}$ & $70 \mathrm{~s}$ \\
\hline Gabustein & & 0 & 0 & 0 & 0 \\
\hline Bohuth 6 & & 0 & 0 & 0 & 0 \\
\hline Aroona (s) & & $100 \mathrm{~S}$ & $90 \mathrm{~S}$ & $100 \mathrm{~s}$ & $100 \mathrm{~S}$ \\
\hline Aroona $* 5 / Y r 1$ & Yr 1 & 0 & 0 & 0 & 0 \\
\hline Aroona $* 6 / Y r 5$ & Yr 5 & 0 & 0 & 0 & 0 \\
\hline Aroona *6/Yr 8 & Yr 8 & $80 S$ & $80 \mathrm{~S}$ & $30 S$ & $30 S$ \\
\hline $\begin{array}{l}\text { Aroona *3/Yr } 15 \\
\text { Commercial Cvs: }\end{array}$ & Yr 15 & 0 & 0 & 0 & 0 \\
\hline Sakha 61 & & 0 & 0 & 0 & 0 \\
\hline Sakha 69 & & $80 \mathrm{~S}$ & $80 \mathrm{~S}$ & $30 \mathrm{~S}$ & $30 S$ \\
\hline Sakha 93 & & 0 & 0 & 0 & 0 \\
\hline Sakha 94 & & 0 & 0 & 0 & 0 \\
\hline Giza 168 & & 0 & 0 & 0 & 0 \\
\hline Gemmeiza 9 & & 0 & 0 & 0 & 0 \\
\hline Gemmeiza 10 & & 0 & 6 & 0 & 0 \\
\hline Sids 1 & & 0 & 0 & 0 & 0 \\
\hline Sids 7 & & $90 \mathrm{~s}$ & $90 \mathrm{~S}$ & $90 \mathrm{~S}$ & $90 \mathrm{~s}$ \\
\hline Sids 9 & & $90 \mathrm{~s}$ & $90 \mathrm{~S}$ & $90 \mathrm{~S}$ & $90 \mathrm{~s}$ \\
\hline
\end{tabular}

A = location Kafr El-Sheikh $\quad$ B = Location Damietta

\section{DISCUSSION}

Stripe rust of wheat is one of the dangerous wheat diseases all over the world. In Egypt it was claimed that it was a sporadic disease ( Abdel -Hak et al., 1972 ), but starting from 1990's it became a familiar disease causing limited epiphytotics every year ( Abu El Naga et al., 1999 ).

The resistance of the resistance entries could be attributed to the presence of resistance genes that have the same or similar reaction as $Y r$ 1, $\operatorname{Yr} 5, \operatorname{Yr} 15, \operatorname{Yr} 17$ and $\operatorname{Yr} \mathrm{A}$. This suggestion is based on the observation that none of the physiologic races tested in Egypt could attack the genes. Similar results were reported by Abu El-Naga et al. (1997, 1998, 1999), Hakim and Ahmed (1998), Hovmoller (1993). However, their resistance could be based on other genes or combination genes. 
The obtained results gave evidence to the presence of 6 and 8 physiologic races of Puccinia striiformis West. The causal agent of wheat stripe rust. These races were identified as 2E0, 2 E22, 6E0, 6E18, 150 E82, 198 E150, 198E156 and 229E223 during 2004/2005 in 3 locations; 2E0, 6E0, 6E148, 6E150, 38E134 and 230E134 during 2005/2006. Similar results were recoded by Ashmawy (2005) in Egypt, Yahyaoui,(2000) and Yahyaoui et al. (2002) in other countries.

It could be concluded from these results that high variability in the genetic materials from which the inoculatum was obtained reflected the variation within physiological races. Since the high virulent races were correlated with the inoculatum from $\mathrm{Yr} 18$ and 2, however less virulence correlated with $\operatorname{Yr} 7$ and $\operatorname{Yr} 6$.

At seedling stage, $Y r$ 's , 1, $3 \mathrm{~V}, 10, \mathrm{SD}, 5,4^{+}$, CV., SP proved to be effective against the previously mentioned physiologic races. The same fact ws noticed within the Avocet and Aroona crussed materials i.e. Yr's 10, 15, 17, 26, 27, SP ( Gabustein and Buhuth 6 ), Aroona Yr's 1, 5, 15.

\section{REFERENCES}

Abdel-Hak, T. M.; Stewart, D. M. and Kamel, A. H.(1972). The current stripe rust situation in the near east countries. Regional wheat workshop. Beirut, Lebanon, 1-29.

Abu El-Naga, S.A.; Khalifa, M.M; Yosussef, W. A. ; Imbaey, I. A; El-Shamy, M. M ; Amer, E.; Shehab El-Din, T.M. and M. M .E. Shamy, 1997. Effect of stripe rust infection on grain yeild in certaion weat cvs . and the economic threshold of chemical control application.National Annual Coordination Meeting (NVRSRP) Egypt . Sep .11-15, 1997: 81-90

Abu El-Naga, S.A.; Khalifa, M.M; Yosussef, W.A. and A.H . Abdel latif 1998. Stripe rust situation during the period (1994-96) with speeial referance to designating genes conferring resitance in certain Egyptian wheat germoplasm. J. Agric. Sci .Mansoura univ. 23 (3) : $1112-1136$

Abu El-Naga, S.A.; Khalifa, M.M.; Bassiouni, A.Y.; Youssef, W.A.; Shehab T.M., Abdel-Latif, A.H. (1999). Revised evaluation for Egyptian wheat germplasm against physiologic pathotypes of stripe rust (Puccinia striiformis West.). J. Agric. Sci. Mansoura Univ., 23(3): 1127 - 1137.

Ashmawy, M.A.(2005).Studies on stripe rust of wheat in Egypt. M.Sc. Thesis, Faculty of Agric., Shibin El- Kom, Dept., of Agric Botany, Minufiya Univ., $80 \mathrm{pp}$.

Hakim, M.S. ; El-Ahmed, A. (1998). The physiologic races of wheat stripe rust Puccinia striiformis West. in SYria during the period 1994-1998 Arab Journal of Plant Protection 16: 7-11.

Hong Ma, and Singh, R. P. (1996). Expression of adult resistance to stripe rust at different growth stages of wheat. Plant Disease. 4: 375-379.

Hovmoller, M.S. (1993). Puccinia striiformis on wheat, biology and varietal resistance. Tenth Danish Plant Protection Conference. Pests and Disease, Lyngby. Denmark, Landburgs, Ministreriet Statenns Planteauls Forsgo. 
Johnson, R. (1988). Durable resistance to yellow (stripe) rust in wheat and its implications in plant breeding. Pages. 63-75. In: Breeding Strategies for Resistance to the Rust of wheat. N.W. Simmonds and S. Ragarm, Eds., Cimmyt, Mexico, D.F., Mexico.

Johnson, R.; Stubbs, R.W.; Fuchs, E. and Chamberlain, N.H. (1972). Nomen clature for phisologic races of Punccinia striiformis infecting wheat. Transactions of the British Mycological Society. 58: 475-480.

Kolmer, S.A. (1997). Virulence in Puccinia recondite f.sp. tritici isolates from Canada to genes for adult-plant resistance to wheat leaf rust. Plant Disease.3:267-271.

McNeal, E.H.; Konzak, C.F.; Smith, E.P.; Tate, W.S.; Russell, T.S. (1971). A uniform system for recording and processing cereal research data. Agriculture Research Service, p. 34-121 Washington, D.C. USA.

Peterson, R.F.; Campbell, A.B. and Hannah, E. (1948). A diagrammatic scale for estimating rust intensity of leaves and stems of cereals. Canadian Journal of Research Section C26: 469-500.

Singh, R.P. (1992). Genetic association of leaf rust resistance gene Lr34 with adult plant resistance to stripe rust in breed wheat. Phytopathology. 82: 835-838.

Singh, R.P. and Rajaram, S. (1994). Genetics of adult a plant resistance to stripe rust in ten spring bread wheats. Euphytica, 7: 1-7.

Tervet, T. and Cassel, R.C. (1951). The use of cyclone collectors in race identification of microscopic particles. Phytopathology. 41 282-285.

Yahyaoui, A. (2000). Emergence of new races of yellow rust of wheat in west and central Asia. Germplasm. Program. Cereal Annual Report for 2000.

Yahyaoui, A. El-Naimi, H. S. and Rabiz, N.(2002). Evaluation of physiological races and virulent of Puccinia striiformis on wheat in Saryia and Lebanon. Plant disease (5) 499- 504. 


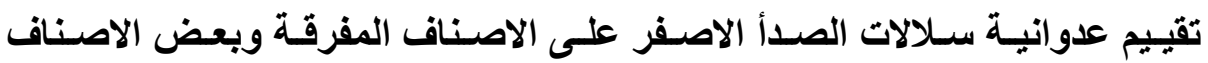

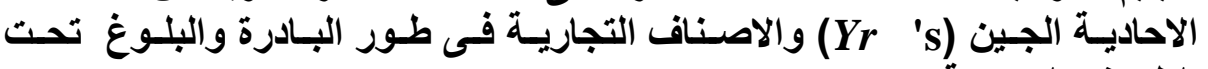
الظروف المصرية الجين

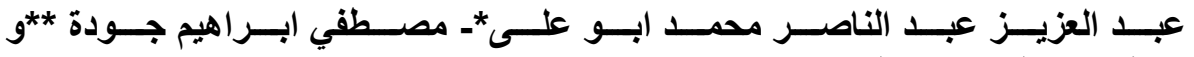

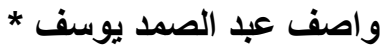
* قسم بحوث امراض القمح ، معهد بحوث امراض النبات ، مركز البحوث الزراعية ـ الجيزة ـ

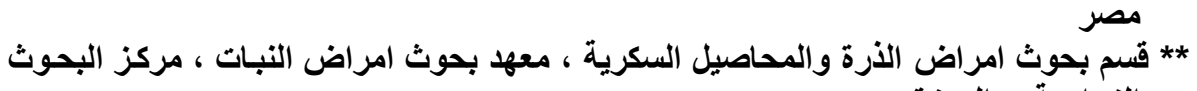

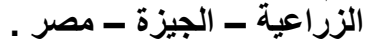

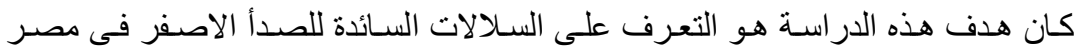

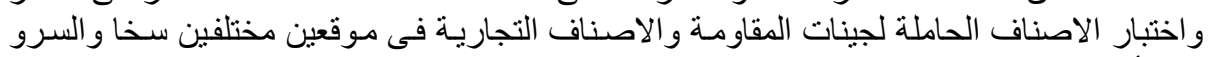

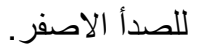

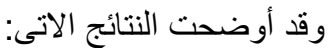
تم تعريف بالتالعالة للصدأ الاصفر خلال موسمين من العينات المتحصل عليها عرفت كالتالى : 2E0,2E22,6E0,6E18,150E82,198E150,198E156,6E148,6E150,38E13 4,230E134, $229 \mathrm{E} 223$.

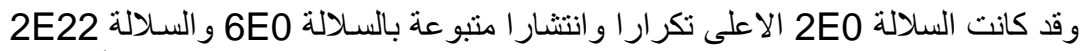

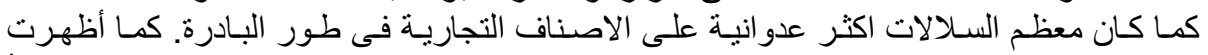

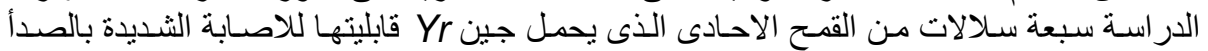

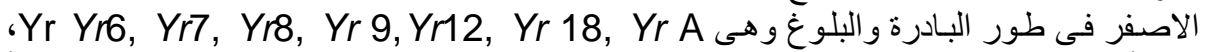

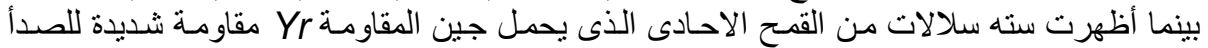

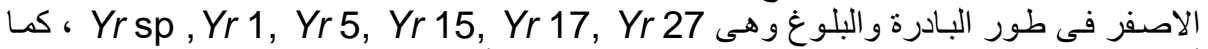

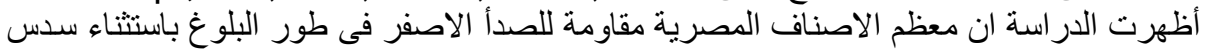

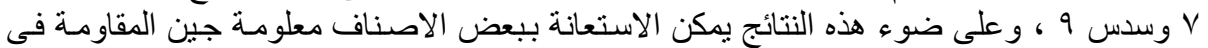

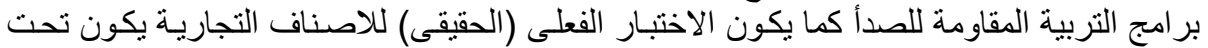

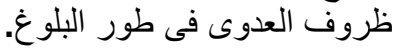


Table (3): Reaction of host differential genotypes, some isogenic lines and some commercial cvs. against stripe rust ( $P$. striiformis) under greenhouse conditions at seedling stage.

\begin{tabular}{|c|c|c|c|c|c|c|c|c|c|c|c|c|c|c|c|}
\hline \multirow[b]{3}{*}{ World differential set : } & \multirow[b]{3}{*}{$Y r$} & \multicolumn{14}{|c|}{$\begin{array}{l}\text { Physiological races reaction at two season } \\
\end{array}$} \\
\hline & & \multicolumn{8}{|c|}{ First season } & \multicolumn{6}{|c|}{ Second season } \\
\hline & & 2E0 & 2E22 & 6E0 & $6 \mathrm{E} 18$ & $150 \mathrm{E} 82$ & $198 \mathrm{E} 150$ & $198 \mathrm{E} 156$ & 229E223 & $2 \mathrm{E} 0$ & $6 \mathrm{E} 0$ & 6E148 & $6 \mathrm{E} 150$ & $38 \mathrm{E} 134$ & 230E134 \\
\hline Chinese 166 & 1 & & & & & & & $\mathrm{~S}$ & & & & & & & \\
\hline Lee & 7 & $\mathrm{~S}$ & $\mathrm{~S}$ & $\mathrm{~S}$ & $\mathrm{~S}$ & $\mathrm{~S}$ & $\mathrm{~S}$ & $\mathrm{~S}$ & $\mathrm{~S}$ & $\mathrm{~S}$ & $\mathrm{~S}$ & $\mathrm{~S}$ & $\mathrm{~S}$ & $\mathrm{~S}$ & $\mathrm{~S}$ \\
\hline Heines Kolben & 6 & & & $\mathrm{~S}$ & $\mathrm{~S}$ & $\mathrm{~S}$ & $\mathrm{~S}$ & $\mathrm{~S}$ & $\mathrm{~S}$ & $\mathrm{~S}$ & $\mathrm{~S}$ & $\mathrm{~S}$ & $\mathrm{~S}$ & $\mathrm{~S}$ & $\mathrm{~S}$ \\
\hline Vilmorin 23 & $3 \mathrm{~V}$ & & & & & & & & & & & & & & \\
\hline Moro & 10 & & & & & $\mathrm{~S}$ & & & & & & & & & \\
\hline Strubes Dikopf & SD & & & & & & & & $\mathrm{S}$ & & & & & $\mathrm{S}$ & $\mathrm{S}$ \\
\hline Suwon $92 \times$ Omar & SU & & & & & & $\mathrm{S}$ & $\mathrm{S}$ & $\mathrm{s}$ & & & & & & $\mathrm{S}$ \\
\hline Clement & $9,2+$ & & & & & $\mathrm{S}$ & $\mathrm{S}$ & $\mathrm{S}$ & $\mathrm{S}$ & & & & & & $\mathrm{s}$ \\
\hline Triticum speleta & 5 & & & & & & & & & & & & & & \\
\hline \multicolumn{16}{|c|}{ European differential Set : } \\
\hline Hybrid 46 & $4+$ & & & & & & & & $\mathrm{S}$ & & & & & & \\
\hline Reichersberg 42 & $7+$ & & $\mathrm{S}$ & & $\mathrm{S}$ & $\mathrm{S}$ & $\mathrm{S}$ & & $\mathrm{S}$ & & & & $\mathrm{S}$ & $\mathrm{S}$ & $\mathrm{S}$ \\
\hline Heines Peko & $6,2+$ & & $\mathrm{S}$ & & & & $\mathrm{S}$ & $\mathrm{S}$ & $\mathrm{S}$ & & & & & & \\
\hline Nord Desprez & ND & & & & & & & $\mathrm{S}$ & $\mathrm{S}$ & & & & & & \\
\hline Compare & 8 & & $\mathrm{~S}$ & & $\mathrm{~S}$ & $\mathrm{~S}$ & $\mathrm{~S}$ & $\mathrm{~S}$ & $\mathrm{~S}$ & & & $\mathrm{~S}$ & $\mathrm{~S}$ & & \\
\hline Carstens V & CV & & & & & & $\mathrm{S}$ & & & & & & & & \\
\hline Spaldings prolific & $\mathrm{SP}$ & & & & & & $\mathrm{S}$ & & $\mathrm{S}$ & & & & & & \\
\hline Heines VII & $2,+$ & & & & & & & $\mathrm{S}$ & $\mathrm{S}$ & & & $\mathrm{S}$ & $\mathrm{S}$ & $\mathrm{S}$ & $\mathrm{S}$ \\
\hline \multicolumn{16}{|c|}{$\begin{array}{l}\text { Supplemental Isogenic } \\
\text { lines: }\end{array}$} \\
\hline Yr $1 /{ }^{*} 6$ Avocet & $Y r 1$ & $\mathrm{R}$ & $\mathrm{R}$ & $\mathrm{R}$ & $\mathrm{R}$ & $\mathrm{R}$ & $\mathrm{R}$ & $\mathrm{R}$ & $\mathrm{R}$ & $\mathrm{R}$ & $\mathrm{R}$ & $\mathrm{R}$ & $\mathrm{R}$ & $\mathrm{R}$ & $\mathrm{R}$ \\
\hline Yr 5/*6 Avocet & Yr5 & $\mathrm{R}$ & $\mathrm{R}$ & $\mathrm{R}$ & $\mathrm{R}$ & $\mathrm{R}$ & $\mathrm{R}$ & $\mathrm{R}$ & $\mathrm{R}$ & $\mathrm{R}$ & $\mathrm{R}$ & $\mathrm{R}$ & $\mathrm{R}$ & $\mathrm{R}$ & $\mathrm{R}$ \\
\hline Yr6/*6 Avocet & Yr6 & $\mathrm{S}$ & $\mathrm{S}$ & $\mathrm{S}$ & $\mathrm{S}$ & $\mathrm{S}$ & $\mathrm{S}$ & $\mathrm{S}$ & $\mathrm{S}$ & $\mathrm{S}$ & $\mathrm{R}$ & $\mathrm{S}$ & $\mathrm{S}$ & $\mathrm{S}$ & $\mathrm{S}$ \\
\hline Yr 7/*6 Avocet & Yr7 & $\mathrm{S}$ & $\mathrm{S}$ & $\mathrm{S}$ & $\mathrm{S}$ & $\mathrm{S}$ & $\mathrm{S}$ & $S$ & $\mathrm{~S}$ & $\mathrm{~S}$ & $\mathrm{~S}$ & $\mathrm{~S}$ & & $\mathrm{~S}$ & $\mathrm{~S}$ \\
\hline Yr 8/*6 Avocet & Yr8 & $\mathrm{s}$ & $\mathrm{S}$ & $\mathrm{s}$ & $\mathrm{S}$ & $\mathrm{S}$ & $\mathrm{S}$ & $\mathrm{S}$ & $\mathrm{S}$ & $\mathrm{S}$ & $\mathrm{S}$ & $\mathrm{S}$ & $\mathrm{S}$ & $\mathrm{S}$ & $\mathrm{S}$ \\
\hline Yr 9/*6 Avocet & Yr9 & $\mathrm{S}$ & $\mathrm{s}$ & $\mathrm{S}$ & $\mathrm{S}$ & $\mathrm{S}$ & $\mathrm{S}$ & $\mathrm{S}$ & $\mathrm{S}$ & $\mathrm{S}$ & $\mathrm{S}$ & $\mathrm{s}$ & $\mathrm{S}$ & $\mathrm{S}$ & $\mathrm{s}$ \\
\hline
\end{tabular}


Abu Aly, A.A.M. et al.

Table (3): Continue.

\begin{tabular}{|c|c|c|c|c|c|c|c|c|c|c|c|c|c|c|c|}
\hline \multirow{2}{*}{\multicolumn{2}{|c|}{ 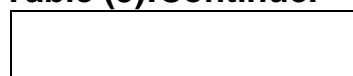 }} & \multicolumn{14}{|c|}{$\begin{array}{l}\text { Physiological races reaction at two seasons } \\
\end{array}$} \\
\hline & & \multicolumn{8}{|c|}{ First season } & \multicolumn{6}{|c|}{ Second season } \\
\hline & $Y r$ & 2E0 & 2E222 & 6E0 & 6E18 & $150 \mathrm{E} 82$ & 198E150 & 198E156 & 229E223 & 2E0 & 6E0 & 6E148 & 6E150 & 38E134 & 230E134 \\
\hline Yr10/*6 Avocet & Yr10 & $\mathrm{R}$ & $\mathrm{R}$ & $\mathrm{R}$ & $\mathrm{R}$ & $\mathrm{R}$ & $\mathrm{R}$ & $\mathrm{R}$ & $\mathrm{R}$ & $\mathrm{R}$ & $\mathrm{R}$ & $\mathrm{R}$ & $\mathrm{R}$ & $\mathrm{R}$ & $\mathrm{R}$ \\
\hline$Y r 11 /{ }^{*} 3$ Avocet & Yr11 & $\mathrm{R}$ & $\mathrm{R}$ & $\mathrm{R}$ & $\mathrm{R}$ & $\mathrm{S}$ & $\mathrm{S}$ & $\mathrm{S}$ & $\mathrm{S}$ & $\mathrm{R}$ & $\mathrm{R}$ & $\mathrm{R}$ & $\mathrm{R}$ & $\mathrm{S}$ & $\mathrm{S}$ \\
\hline$Y r 12 /{ }^{*} 6$ Avocet & Yr12 & $\mathrm{R}$ & $\mathrm{R}$ & $\mathrm{R}$ & $\mathrm{R}$ & $\mathrm{S}$ & $\mathrm{S}$ & $\mathrm{S}$ & $S$ & $\mathrm{R}$ & $\mathrm{R}$ & $\mathrm{R}$ & $\mathrm{R}$ & $\mathrm{S}$ & $\mathrm{S}$ \\
\hline$Y r 15 /{ }^{*} 6$ Avocet & Yr15 & $\mathrm{R}$ & $\mathrm{R}$ & $\mathrm{R}$ & $\mathrm{R}$ & $\mathrm{R}$ & $\mathrm{R}$ & $\mathrm{R}$ & $\mathrm{R}$ & $\mathrm{R}$ & $\mathrm{R}$ & $\mathrm{R}$ & $\mathrm{R}$ & $\mathrm{R}$ & $\mathrm{R}$ \\
\hline Yr18/*3 Avocet & Yr18 & $\mathrm{S}$ & $\mathrm{S}$ & $\mathrm{S}$ & $\mathrm{S}$ & $\mathrm{S}$ & $\mathrm{S}$ & $\mathrm{S}$ & $\mathrm{S}$ & $\mathrm{S}$ & $\mathrm{S}$ & $\mathrm{S}$ & $\mathrm{S}$ & $\mathrm{S}$ & $\mathrm{S}$ \\
\hline$Y r 17 / * 4$ Avocet & Yr17 & $\mathrm{R}$ & $\mathrm{R}$ & $\mathrm{R}$ & $\mathrm{R}$ & $\mathrm{R}$ & $\mathrm{R}$ & $\mathrm{R}$ & $\mathrm{R}$ & $\mathrm{R}$ & $\mathrm{R}$ & $\mathrm{R}$ & $\mathrm{R}$ & $\mathrm{R}$ & $\mathrm{R}$ \\
\hline Yr 26/*6 Avocet & Yr26 & $\mathrm{R}$ & $\mathrm{R}$ & $\mathrm{R}$ & $\mathrm{R}$ & $\mathrm{R}$ & $\mathrm{R}$ & $\mathrm{R}$ & $\mathrm{R}$ & $\mathrm{R}$ & $\mathrm{R}$ & $\mathrm{R}$ & $\mathrm{R}$ & $\mathrm{R}$ & $\mathrm{R}$ \\
\hline Yr27 & Yr27 & $\mathrm{R}$ & $R$ & $\mathrm{R}$ & $R$ & $\mathrm{R}$ & $R$ & $R$ & $R$ & $\mathrm{R}$ & $\mathrm{R}$ & $R$ & $\mathrm{R}$ & $R$ & $\mathrm{R}$ \\
\hline Yr A/ Avocet & YrA & $S$ & S & S & S & $\mathrm{S}$ & $\mathrm{S}$ & $S$ & $\mathrm{~S}$ & $\mathrm{~S}$ & $\mathrm{~S}$ & $\mathrm{~S}$ & $\mathrm{~S}$ & $\mathrm{~S}$ & $\mathrm{~S}$ \\
\hline YrSP/Avocet & YrSP & $\mathrm{R}$ & $\mathrm{R}$ & $\mathrm{R}$ & $\mathrm{R}$ & $\mathrm{s}$ & $\mathrm{R}$ & $\mathrm{R}$ & $\mathrm{S}$ & $\mathrm{R}$ & $\mathrm{R}$ & $\mathrm{R}$ & $\mathrm{R}$ & $\mathrm{R}$ & $\mathrm{R}$ \\
\hline Avocet S & & $\mathrm{S}$ & $\mathrm{S}$ & $\mathrm{S}$ & $\mathrm{S}$ & $\mathrm{S}$ & $\mathrm{S}$ & $\mathrm{S}$ & $\mathrm{S}$ & $\mathrm{S}$ & $\mathrm{S}$ & $\mathrm{S}$ & $\mathrm{S}$ & $\mathrm{S}$ & $\mathrm{S}$ \\
\hline Gobustein & & $\mathrm{R}$ & $\mathrm{R}$ & $\mathrm{R}$ & $\mathrm{R}$ & $\mathrm{R}$ & $\mathrm{R}$ & $\mathrm{R}$ & $\mathrm{R}$ & $\mathrm{R}$ & $\mathrm{R}$ & $\mathrm{R}$ & $\mathrm{R}$ & $\mathrm{R}$ & $\mathrm{R}$ \\
\hline Bohuth 6 & & $\mathrm{R}$ & $\mathrm{R}$ & $\mathrm{R}$ & $\mathrm{R}$ & $\mathrm{R}$ & $\mathrm{R}$ & $\mathrm{R}$ & $\mathrm{R}$ & & $\mathrm{R}$ & $\mathrm{R}$ & $\mathrm{R}$ & $\mathrm{R}$ & $\mathrm{R}$ \\
\hline Aroonas & & $\mathrm{S}$ & $\mathrm{S}$ & $\mathrm{S}$ & $\mathrm{S}$ & $\mathrm{S}$ & $\mathrm{S}$ & $\mathrm{S}$ & $\mathrm{S}$ & $\mathrm{S}$ & $\mathrm{S}$ & $\mathrm{S}$ & $\mathrm{s}$ & $\mathrm{S}$ & $\mathrm{S}$ \\
\hline Yr 1/*5 Aroona & $Y r 1$ & $\mathrm{R}$ & $R$ & $\mathrm{R}$ & $\mathrm{R}$ & $\mathrm{R}$ & $\mathrm{R}$ & $\mathrm{R}$ & $\mathrm{R}$ & $\mathrm{R}$ & $\mathrm{R}$ & $\mathrm{R}$ & $\mathrm{R}$ & $\mathrm{R}$ & $\mathrm{R}$ \\
\hline Yr 5/*6 Aroona & Yr5 & $\mathrm{R}$ & $\mathrm{R}$ & $\mathrm{R}$ & $\mathrm{R}$ & $\mathrm{R}$ & $\mathrm{R}$ & $\mathrm{R}$ & $\mathrm{R}$ & $\mathrm{R}$ & $\mathrm{R}$ & $\mathrm{R}$ & $\mathrm{R}$ & $\mathrm{R}$ & $\mathrm{R}$ \\
\hline Yr 8/*6 Aroona & Yr8 & $\mathrm{S}$ & $\mathrm{S}$ & $\mathrm{S}$ & $\mathrm{S}$ & $\mathrm{S}$ & $\mathrm{S}$ & $\mathrm{S}$ & $\mathrm{S}$ & $\mathrm{S}$ & $\mathrm{S}$ & $\mathrm{S}$ & $\mathrm{S}$ & $\mathrm{S}$ & $\mathrm{S}$ \\
\hline Yr15/*3 Aroona & Yr15 & $\mathrm{R}$ & $\mathrm{R}$ & $\mathrm{R}$ & $\mathrm{R}$ & $\mathrm{R}$ & $\mathrm{R}$ & $\mathrm{R}$ & $\mathrm{R}$ & $\mathrm{R}$ & $\mathrm{R}$ & $\mathrm{R}$ & $\mathrm{R}$ & $\mathrm{R}$ & $\mathrm{R}$ \\
\hline \multicolumn{16}{|l|}{ Commercial Cvs : } \\
\hline Sakha 61 & & $\mathrm{~S}$ & $\mathrm{~S}$ & $\mathrm{~S}$ & $\mathrm{~S}$ & $\mathrm{~S}$ & $\mathrm{~S}$ & $\mathrm{~S}$ & $\mathrm{~S}$ & $\mathrm{~S}$ & $\mathrm{~S}$ & $\mathrm{~S}$ & $\mathrm{~S}$ & $\mathrm{~S}$ & $\mathrm{~S}$ \\
\hline Sakha 69 & & $\mathrm{~S}$ & $\mathrm{~S}$ & $\mathrm{~S}$ & $S$ & $\mathrm{~S}$ & $\mathrm{~S}$ & $\mathrm{~S}$ & $\mathrm{~S}$ & $\mathrm{~S}$ & $\mathrm{~S}$ & $\mathrm{~S}$ & $\mathrm{~S}$ & $\mathrm{~S}$ & $\mathrm{~S}$ \\
\hline Sakha 93 & & $\mathrm{~S}$ & $\mathrm{~S}$ & $S$ & $\mathrm{~S}$ & $\mathrm{~S}$ & $\mathrm{~S}$ & $\mathrm{~S}$ & $\mathrm{~S}$ & $\mathrm{~S}$ & $\mathrm{~S}$ & $\mathrm{~S}$ & $\mathrm{~S}$ & $\mathrm{~S}$ & $\mathrm{~S}$ \\
\hline Sakha 94 & & $\mathrm{~S}$ & $\mathrm{~S}$ & $\mathrm{~S}$ & $\mathrm{~S}$ & $\mathrm{~S}$ & $\mathrm{~S}$ & $\mathrm{~S}$ & $\mathrm{~S}$ & $\mathrm{~S}$ & $\mathrm{~S}$ & $\mathrm{~S}$ & $\mathrm{~S}$ & $\mathrm{~S}$ & $\mathrm{~S}$ \\
\hline Giza 168 & & $\mathrm{~s}$ & $\mathrm{~s}$ & $\mathrm{~s}$ & $\mathrm{~s}$ & $\mathrm{~s}$ & $\mathrm{~s}$ & $\mathrm{~S}$ & $S$ & $S$ & $\mathrm{~S}$ & $\mathrm{~S}$ & $\mathrm{~S}$ & $S$ & $S$ \\
\hline Gemmeza 9 & & $\mathrm{~S}$ & $\mathrm{~S}$ & $\mathrm{~S}$ & $\mathrm{~S}$ & $\mathrm{~S}$ & $\mathrm{~S}$ & $\mathrm{~S}$ & $\mathrm{~S}$ & $\mathrm{~S}$ & $\mathrm{~S}$ & $\mathrm{~S}$ & $S$ & S & S \\
\hline Gemmeza 10 & & $\mathrm{~S}$ & S & $S$ & S & $S$ & $S$ & $S$ & $\mathrm{~S}$ & $S$ & $S$ & S & $S$ & $\mathrm{~S}$ & S \\
\hline Sids 1 & & $\mathrm{~S}$ & $\mathrm{~S}$ & $S$ & $\mathrm{~S}$ & $S$ & $S$ & $S$ & $\mathrm{~S}$ & $S$ & $\mathrm{~S}$ & $S$ & $\mathrm{~S}$ & $\mathrm{~S}$ & $\mathrm{~S}$ \\
\hline Sids 7 & & S & $\mathrm{S}$ & $\mathrm{S}$ & S & $S$ & $S$ & $\mathrm{~S}$ & $S$ & $S$ & S & S & $\mathrm{S}$ & $\mathrm{S}$ & $S$ \\
\hline Sids 9 & & $\mathrm{~S}$ & $\mathrm{~S}$ & $\mathrm{~S}$ & $\mathrm{~S}$ & $S$ & $\mathrm{~S}$ & $\mathrm{~S}$ & $\mathrm{~S}$ & $\mathrm{~S}$ & $\mathrm{~S}$ & $\mathrm{~S}$ & $\mathrm{~S}$ & $\mathrm{~S}$ & $S$ \\
\hline
\end{tabular}

